\title{
Isu-Isu Pendidikan dalam Kampanye Pilkada Kabupaten Dompu 2015
}

\author{
1) Ilyas Yasin, 2) Enung Nurhasanah \\ 1) Dosen Program Studi Pendidikan Sejarah, STKIP Yapis Dompu \\ 2) Dosen Program Studi Pendidikan Bahasa Inggris, STKIP Yapis Dompu \\ E-mail: ilyasdompu73@yahoo.co.id
}

Article History: Received: 2020-10-20 || Revised: 2021-01-03 || Published: 2021-01-30

Sejarah Artikel : Diterima: 2020-10-20 || Direvisi: 2021-01-03 || Dipublikasi: 2021-01-30

\begin{abstract}
$\mathrm{n}$ the context of the regional head election (Pilkada) in Dompu Regency, the issue of education is interesting not only because this issue is still crucial, but also the fact that candidates see the world of education as a basis for support and political legitimacy is quite important in every Pilkada campaign in the area. The long-term objective to be achieved in this research is to encourage stakeholders, particularly the Dompu Regency government, to put the education sector in the mainstream in making regional development policies. This research can also assist future candidates for the district head of Dompu in formulating the theme of the education campaign, program and policy that will be carried out. While the specific target of this research is the knowledge of the political or educational policies of each candidate for district head of Dompu, the forms of educational policies to be implemented, how important educational issues are in the campaign themes of the candidates, how they view educational issues among the issues. other developments, and how to execute the education policies that have been drawn up if elected later. This research was conducted using qualitative methods. The data were collected by means of observation and document study, while the data analysis was carried out in a descriptive-qualitative manner. This research concludes that apart from not being a major issue in the Pilkada campaign, the solution to the educational problems offered by candidates is also partial and only relies on a welfare approach.
\end{abstract}

Keywords: Politics, Education, Regional Head Election.

\begin{abstract}
Abstrak
Dalam konteks pemilihan kepala daerah (Pilkada) di Kabupaten Dompu, masalah pendidikan menarik bukan hanya karena persoalan ini masih krusial, tapi juga fakta bahwa para calon memandang dunia pendidikan sebagai basis dukungan dan legitimasi politik cukup penting dalam setiap kampanye Pilkada di daerah tersebut. Tujuan jangka panjang yang akan dicapai dalam penelitian ini adalah mendorong para pemangku kepentingan (stakeholders), khususnya pemerintah Kabupaten Dompu, agar menempatkan sektor pendidikan berada di arus utama dalam pembuatan kebijakan pembangunan di daerah. Penelitian ini juga dapat membantu para calon bupati Dompu yang akan datang dalam merumuskan tema kampanye, program maupun kebijakan pendidikan yang akan diusungnya. Sedangkan target khusus penelitian ini adalah diketahuinya politik atau kebijakan pendidikan dari masing-masing calon bupati Dompu, bentuk-bentuk kebijakan pendidikan yang akan dijalankan, seberapa penting isu pendidikan dalam tema-tema kampanye para calon, bagaimana mereka memandang isu pendidikan di antara isu-isu pembangunan lainnya, dan bagaimana cara mengeksekusi kebijakan pendidikan yang telah disusun jika terpilih nantinya. Penelitian ini dilaksanakan dengan metode kualitatif. Pengumpulan data dilakukan dengan cara observasi dan studi dokumen, sedangkan analisis data dilakukan secara deksriptif-kualitatif. Penelitian ini menyimpulkan bahwa selain belum menjadi isu utama dalam kampanye Pilkada, penyelesaian masalah pendidikan yang ditawarkan para calon juga masih bersifat parsial serta hanya mengandalkan pendekatan kesejahteraan.
\end{abstract}

Kata kunci: Politik, Pendidikan, Pilkada.

\section{PENDAHULUAN}

Dalam pentas politik modern pendidikan seringkali menjadi salah satu isu strategis yang digunakan oleh para elit untuk meraih dan memobilisasi dukungan publik dalam ajang perebutan jabatan-jabatan politik seperti Pemilihan Umum (Pemilu) atau Pemilihan Kepala Daerah (Pilkada). Hal itu didasarkan pada fakta bahwa pendidikan tidak sekadar berfungsi mengembangkan potensi 
individu-individu dalam masyarakat tapi juga secara langsung ikut memengaruhi kualitas kehidupan negara secara luas (Razik\&Swanson, 1995). Itulah sebabnya setiap kebijakan pendidikan merefleksikan pilihan-pilihan politik, tradisi, nilai dan konsepsi masa depan sebuah negara (UNESCO, 1972: 170). Bahkan menurut Olsen dkk (Tilaar dan Nugroho, 2008: 267) kebijakan pendidikan merupakan kunci bagi keamanan, keberlanjutan dan eksistensi dunia global. Sebagai salah satu aspek yang bersentuhan langsung dengan hajat hidup orang banyak maka kebijakan-kebijakan di bidang pendidikan tentu akan ikut memengaruhi persepsi dan pilihan seseorang dalam menyalurkan aspirasi politik yang dimilikinya dalam pelaksanaan Pemilu maupun Pilkada.

Pilkada secara langsung yang dilakukan sejak 2004 telah membawa beberapa implikasi mendasar dalam sistem perpolitikan di Indonesia baik dari aspek rekrutmen elit maupun isu-isu kampanye politik di daerah. Dari aspek rekrutmen, studi Pramusinto (2010: 307-308) menunjukkan bahwa otonomi daerah tidak hanya melahirkan kepemimpinan yang inovatif tapi juga sumber-sumber rekrutmen kepemimpinan yang lebih bervariasi. Jika pada masa Orde Baru kepemimpinan didominasi kalangan militer dan birokrat maka sejak otonomi daerah pola kepemimpinan berasal dari berbagai kalangan seperti dunia usaha (Kota Yogyakarta dan Gorontalo), pendidik (Jembrana, Blitar, Bantaeng, Bojonegoro), aktivis politik (Blitar, Kebumen, Solo), birokrat muda (Solok), tokoh perempuan (Kebumen) dan kalangan profesional (Kota Bandung). Sedangkan dari aspek isu kampanye, Pilkada telah menyebabkan isu-isu kampanye para calon kepala daerah memiliki dimensi kedekatan (proximity) dengan berbagai persoalan yang dihadapi secara langsung oleh masyarakat pemilih, sehingga setiap pilihan isu kampanye yang disampaikan para kandidat akan turut memengaruhi tingkat elektabilitas kandidat, termasuk isuisu di bidang pendidikan.

Pada 2015 secara nasional terdapat 269 daerah yang terdiri atas 9 provinsi, 36 kota dan 224 kabupaten melakukan Pilkada secara serentak (Suara KPU, edisi Maret-April 2015). Di Provinsi Nusa Tenggara Barat (NTB) sendiri terdapat tujuh kabupaten/kota yang menggelar Pilkada serentak yakni Kabupaten Sumbawa Besar, Kabupaten Sumbawa Barat, Kabupaten Dompu, Kabupaten Bima, Kota Mataram, Kabupaten Lombok Tengah dan Kabupaten Lombok Utara Uurnal KPU Dompu, Juli-Agustus 2015). Meskipun Pilkada digelar pada awal Desember 2015, namun sejak pertengahan tahun 2014 geliat politik kabupaten Dompu sudah mulai bermunculan. Beberapa kandidat yang akan mencalonkan diri dalam Pilkada melakukan berbagai upaya untuk menarik simpatik masyarakat baik secara terbuka maupun tersamar, misalnya melalui berbagai acara sosial kemasyarakatan (seperti pernikahan), pertemuan-pertemuan informal, mensponsori berbagai kegiatan perlombaan olahraga, maupun dengan menggunakan media dan alat seperti spanduk, baliho dan kalender. Berbagai upaya tersebut tidak lain dimaksudkan untuk membangun citra positif guna meraih dukungan publik, baik yang dilakukan calon pendatang baru maupun petahana (incumbent).

Di Kabupaten Dompu maupun NTB umumnya, secara politik isu pendidikan menjadi menarik karena berhubungan dengan masih rendahnya kualitas sumberdaya manusia. Di tingkat provinsi, Indeks Pembangunan Manusia (IPM) NTB masih sangat rendah, yakni menempati urutan 32 dari 33 provinsi dengan indeks 63 pada tahun 2007. Posisi tersebut belum bergeser sampai tahun 2009. Tahun 2005 NTB bahkan merupakan salah satu dari tujuh provinsi yang memiliki proporsi angka buta huruf yang relatif tinggi yaitu 18,27\% (Sulistyastuti, 2007: 19). Kendati Angka Partisipasi Kasar (APK) melebihi 100\% dan Angka Partisipasi Murni (APM) cukup tinggi (SD/MI 95,15\% tahun 2002/2003, SMP/MTs $76,15 \%$ pada 2006) tapi IPM NTB dalam tiga tahun terakhir tetap rendah yaitu 60,6 (2004), 62,4 (2005) dan 63 (2006). Peringkat ini berada di bawah rata-rata IPM nasional pada tahun yang sama yaitu 68,7; 69,4; dan 70,1 (BPS NTB, 2008). Demikian juga, meski Angka Melek Huruf (AMH) cukup tinggi yaitu mencapai 80,1\% untuk usia di atas 15 tahun, tapi Rata-rata Lama Sekolah (RLS) hanya mencapai 6,7 tahun atau setingkat kelas satu SMP. Angka drop out (DO) juga cukup tinggi terutama di tingkat SD yaitu 29.724 siswa $(5,51 \%)$, sedangkan di SMP $4,76 \%$, SMA 4,23\% dan SMK 6,31\%.

Di Kabupaten Dompu, isu pendidikan paling tidak menghadapi dua tantangan berat. Pertama, masih tingginya angka kemiskinan yakni mencapai 57.531 jiwa $(27,87 \%)$ dari keseluruhan penduduk 213.185 jiwa sehingga menempatkan Kabupaten Dompu berada di urutan kedua dari sembilan kabupaten/kota yang berpenduduk miskin di Provinsi NTB. Kedua, angka buta aksara 
untuk usia 10 tahun ke atas juga tergolong tinggi yaitu 20,17\% tahun pada 2006. Angka Melek Huruf mencapai 82,80\%, Rata-rata Lama Sekolah (RLS) 7,00 tahun dan drop out (DO) 4,88\%. Kondisi ini menyebabkan IPM Kabupaten Dompu pada 2007 berada berada di urutan 5 tingkat provinsi atau urutan 424 secara nasional. Fakta-fakta ini menunjukkan bahwa ke depan berbagai persoalan pendidikan senantiasa menjadi isu krusial yang akan dihadapi oleh elit yang memimpin Kabupaten Dompu. Oleh karena itu, menarik untuk mencermati isu-isu pendidikan dalam kampanye Pilkada Kabupaten Dompu 2015. Meski selama ini janji-janji kampanye seringkali tidak memiliki konsekuensi hukum, namun betapapun bahwa janji kampanye menjadi cermin dari visi dan aspirasi politik dari calon kepala daerah bersangkutan. Faktanya, terdapat beberapa daerah yang tergolong sukses membuat inovasi di bidang pendidikan sehingga kualitas kehidupan masyarakatnya dapat ditingkatkan.

Tulisan ini bertujuan untuk melihat bagaimana politik pendidikan dalam kampanye Pilkada Kabupaten Dompu tahun 2015. Apakah bidang pendidikan menjadi perhatian para calon bupati, bagaimana mereka memandang isu pendidikan dalam kerangka kebijakan pembangunan di daerah jika kelak terpilih? Seberapa pentingkah posisi pendidikan dibandingkan sektor-sektor lain seperti kesehatan, ekonomi, pertanian dan lain-lain? Tulisan ini merupakan hasil penelitian kualitatif yang dilakukan selama lima bulan masa kampanye Pilkada di Kabupaten Dompu yakni 27 Agustus-5 Desember 2015. Sasaran penelitian ini adalah seluruh calon atau pasangan calon bupati Dompu periode 2015-2020 yang telah ditetapkan dan disahkan oleh Komisi Pemilihan Umum Daerah (KPUD) Kabupaten Dompu serta yang melakukan kampanye dalam pemilihan kepala daerah kabupaten Dompu tahun 2015.

\section{METODE PENELITIAN}

Penelitian ini dilaksanakan di sejumlah wilayah yang menjadi tempat kampanye para pasangan calon bupati Dompu yang tersebar di 8 kecamatan di Kabupaten Dompu yakni Kecamatan Dompu, Woja, Pajo, Hu'u, Manggelewa, Kempo, Kilo dan Pekat. Data primer diperoleh melalui observasi saat para pasangan calon maupun tim sukses melakukan kampanye, pidato maupun acara debat antar pasangan calon yang difasilitasi KPUD, di samping melalui publikasi media massa seperti pemberitaan di koran dan siaran televisi lokal. Sedangkan data sekunder dikumpulkan melalui berbagai bahan bacaan dan sumber yang relevan dengan penelitian ini. Analisis data mengacu pada Miles dan Huberman (1985) yang terdiri atas tiga aktivitas yakni reduksi data (data reduction), penyajian data (data display), dan kesimpulan/verifikasi (conclusion drawing/verification).

\section{HASIL DAN PEMBAHASAN}

\section{A. Hasil Penelitian}

Berdasarkan Surat Keputusan Komisi Pemilihan Umum Daerah (KPUD) Kabupaten Dompu Nomor 50/Kpts/KPU-Kab-017.433877/Tahun 2015 tanggal 24 Agustus 2015 terdapat empat pasangan calon (Paslon) Bupati dan Wakil Bupati Dompu tahun 2015 yakni (a) Drs. H. Bambang M. Yasin-Arifuddin, SH yang diusung Partai Nasdem (3 kursi), Partai Gerindra ( 3 kursi) dan Partai Hanura (1 kursi), (b) Syafruddin, SAP-Rafiuddin, SE yang diusung PAN (4 kursi) dan PKB ( 3 kursi); (c) H. Mulyadin, SH, MH-Kurniawan Ahmadi yang diusung PKS (3 kursi), PDI-P (3 kursi) dan Partai Demokrat (2 kursi) dan (d) H. Abubakar Ahmad, SH-Kisman, SH yang diusung PPP (3 kursi), Partai Golkar (2 kursi) dan PBB (3 kursi). Berdasarkan komposisi kursi partai politik di DPRD Kabupaten Dompu, keempat pasangan calon di atas masing-masing diusung oleh 7 kursi parpol (Paslon Bambang M. Yasin-Arifuddin dan Syafruddin-Rafiuddin) dan 8 kursi parpol (Mulyadin-Kurniawan Ahmadi dan Abubakar Ahmad-Kisman).

Dilihat dari latarbelakang pekerjaan, keempat Paslon berasal dari profesi yang beragam sejak dari politisi (Rafiuddin dan Kurniawan Ahmadi), birokrat (Syafruddin, Mulyadin), birokratpengusaha (Arifuddin), pengusaha (Bambang M. Yasin), birokrat-politisi (Abubakar Ahmad) hingga pengacara-aktivis LSM (Kisman). Dari keempat Paslon di atas ternyata tak ada satu calon pun yang murni datang atau berasal dari dunia pendidikan. Untuk memperkenalkan diri maupun meraih simpati publik, ternyata tidak seluruh Paslon bupati Dompu secara eksplisit menyampaikan atau mencantumkan visi dan misi mereka baik melalui alat peraga kampanye, publikasi, saat kampanye maupun dalam sesi debat antarkandidat bupati. Dari keempat Paslon, hanya Paslon Syafruddin 
Yasin dan Rafiuddin H. Anas (Lamba Rasa) dan pasangan H. Mulyadin dan Kurniawan Ahmadi (MULYA) yang secara resmi mencantumkan visi dan misinya, terutama melalui alat peraga kampanye seperti baliho, spanduk, stiker, dan pamflet. Pasangan Syafruddin Yasin dan Rafiuddin H. Anas (Lamba Rasa) memiliki visi "Terwujudnya Dompu yang unggul, sejahtera, maju, religius dan berdaya saing". Sedangkan misi adalah (1) mewujudkan pemerintahan yang unggul dalam pelayanan publik (2) membangun masyarakat sejahtera melalui peningkatan perekonomian (3) maju dalam kualitas hidup, religius dalam kehidupan beragama, sosial dan budaya serta menciptakan sumberdaya manusia yang berdaya saing dalam bingkai nggahi rawi pahu1.

Pasangan H. Mulyadin dan Kurniawan Ahmadi (MULYA), mengusung slogan "Bangga Bangun Desa" (dan belakangan ditambah menjadi "Menata Kota" sehingga menjadi "Bangga Bangun Desa, Menata Kota"). Visi pasangan ini adalah: "Terwujudnya masyarakat Dompu yang maju, mandiri dan religius dengan dinafasi semangat Mbolo Weki" (gotong royong). Misi pasangan ini adalah: (a) meningkatkan kemampuan dan keadilan ekonomi (b) mengembangkan pendidikan dan teknologi yang bermutu dan berorientasi pasar (c) peningkatan derajat kesehatan masyarakat (d) melibatkan partisipasi masyarakat dalam pengambilan keputusan publik (e) peningkatan upaya penegakkan hukum (f) meningkatkan pengelolaan dan pelestarian sumberdaya alam. Sedangkan pasangan $\mathrm{H}$. Bambang M. Yasin dan Arifuddin (HBY-Arif) mengusung visi maupun misi dalam beberapa kata saja, yakni visi: "Mandiri dan Religius" dan misi "Membuat Masyarakat Dompu Mampu Membayar". Kendati mungkin dimaksudkan agar lebih sederhana dan mudah diingat oleh publik, namun secara teoretis visi Paslon ini lebih lepat disebut sebagai slogan, sedangkan rumusan misinya justru lebih cocok sebagai visi meski secara tata kebahasaan belum menjadi kalimat yang sempurna karena tidak memiliki predikat. Sementara pasangan H. Abubakar Ahmad dan Kisman Pangeran (OK) bahkan tak memiliki visi dan misi tapi langsung mengacu pada program kegiatan yakni (1) siap mengembalikan program pendidikan dan kesehatan gratis (2) menaikkan tunjangan kinerja PNS (3) menaikkan gaji honorer daerah (4) memberikan kepastian hukum kepada petani penggarap (5) menaikkan gaji pegawai sukarela, Guru Tidak Tetap, Guru Tetap Yayasan, Pegawai Tidak Tetap, Guru Bantu Daerah, guru PAUD, guru TK, dan guru daerah terpencil (6) membagi pakaian dinas gratis tiap tahun (7) memberi gaji untuk guru ngaji, marbot, dan ketu RT/RW (8) menaikkan harga jagung dan gabah (9) bantuan untuk nelayan (10) pemberian modal untuk pedagang bakulan (11) memajukan dunia pariwisata.

Dalam kampanye di Lapangan Bola Desa Ranggo Kec. Pajo tanggal 19 September 2015, pasangan HBY-Arif tidak secara spesifik mengungkapkan program kerja di bidang pendidikan. Sebagai petahana, pasangan ini banyak menyinggung sejumlah capaian pada periode pemerintahan sebelumnya. Di bidang pertanian pasangan ini menyebut misalnya (1) pembukaan lahan baru untuk pertanian khususnya jagung (2) pemberian bibit jagung gratis untuk para petani (3) penyediaan kebutuhan pupuk (4) bantuan pembangunan tambak rakyat (5) pembangunan Sentra Peternakan Rakyat (SPR) (6) penerbitan sertifikat tanah gratis seluas 16.000 persil tanah tegalan. Di bidang pembangunan infrastruktur pasangan calon ini menyebut capaian seperti (a) pembangunan Dam Rababaka Kompleks senilai 1 triliun rupiah yang akan mengairi lahan di Kecamatan Woja dan Kecamatan Manggelewa (b) pembangunan dan beroperasinya Pabrik Tebu di desa Doropeti Kecamatan Pekat, beroperasinya perusahaan tambang PT. Sumbawa Timur Maining di Kecamatan Hu'u, serta pabrik pengolahan jagung di Kecamatan Manggelewa. Dari sektor ekonomi pasangan HBY-Arif juga menunjukkan penurunan angka kemiskinan di Dompu dari 21\% (2010) menjadi 14\% (2015). Di sisi lain daya beli masyarakat Dompu (pendapatan perkapita) meningkat menjadi urutan pertama dari 8 kabupaten/kota se NTB dalam lima tahun terakhir. Di bidang birokrasi pemerintahan pasangan ini juga menjanjikan akan segera mengangkat sejumlah pegawai honorer daerah kategori-2 (K-2). Pasangan ini memandang, karena tiap tahun terdapat ratusan sarjana maka tidak mungkin seluruhnya dapat ditampung dalam birokrasi pemerintahan. Karena itu pasangan ini berpandangan bahwa masuknya investasi swasta di Dompu melalui beroperasinya sejumlah pabrik dan perusahaan tambang dengan sendirinya akan membuka lapangan kerja baru bagi para sarjana.

\footnotetext{
${ }^{1}$ Nggahi rawi pahu merupakan motto atau slogan resmi Pemda Kabupaten Dompu yang tertera dalam lambang daerah Dompu. Dalam bahasa Bima-Dompu secara harfiah nggahi berarti perkataan, rawi=perbuatan, dan pahu=bukti perbuatan. Jadi, motto ini mengandung pengertian tentang pentingnya akan satunya kata dengan perbuatan.
} 
Dalam kampanye di desa nelayan, desa Jambu Kecamatan Pajo tanggal 9 September 2015 pasangan MULYA banyak menyampaikan program yang berkaitan dengan pembangunan ekonomi dan pembangunan fasilitas dan sarana untuk nelayan dan petani seperti pengadaan perahu, jaring tangkap, mesin ketinting, pelabuhan, Tempat Pendaratan Ikan (TPI), pembangunan pabrik es dll. Di bidang pertanian, pasangan MULYA menjanjikan pengadaan sumur bor untuk meningkatkan produktivitas petani, pembangunan infrastruktur seperti pembanguna jalan lingkungan dan jalan usaha tani. Di bidang sosial budaya menjanjikan pembangunan fasilitas olahraga, santunan anak yatim, guru mengaji dan marbot masjid, serta pemberian modal usaha yang bersumber dari dana hibah sebesar Rp 4 juta perorang khususnya untuk kaum ibu yang membuka usaha kecil/bakulan. Pasangan MULYA melalui Kurniawan Ahmadi menjanjikan bahwa dengan proyeksi pendapatan tahun 2016 sebesar Rp 1,18 trilyun pasangan MULYA akan memberikan pendidikan dan kesehatan gratis. Kurniawan Ahmadi memproyeksikan bahwa selama setahun Kesehatan Gratis dapat melayani 300 orang perdesa serta satu unit mobil ambulans sehingga jika 300 orang perdesa dikalikan 90 desa maka akan membutuhkan dana sebesar $\mathrm{Rp} \mathrm{1,5} \mathrm{milyar,} \mathrm{sedangkan} \mathrm{mobil}$ ambulans desa dialokasikan 15 unit pertahun sehingga menghabiskan anggaran sebesar Rp 3 milyar pertahun. Sementara untuk warga miskin pasangan ini menjanjikan fasilitas BPJS Miskin.

Di bidang pendidikan Kurniawan Ahmadi menyampaikan keprihatinannya terutama terhadap nasib Guru Tidak Tetap (GTT) yang hanya digaji Rp 100.000 (seratus ribu rupiah) perbulan. Jumlah GTT di Kabupaten Dompu dari tingkat Taman Kanak-Kanak hingga SMA berjumlah 2.605 orang. Jika terpilih MULYA menjanjikan gaji GTT minimal Rp 300 ribu perbulan dengan alokasi APBD Rp 1 milyar. Kurniawan Ahmadi juga menyatakan keprihatinannya terhadap mutasi guru yang kental dengan nuansa politis, sehingga menyebabkan distribusi guru yang timpang dan hanya berkonsentrasi di wilayah perkotaan, sementara sejumlah sekolah di wilayah pinggiran justru kekurangan guru. Di beberapa wilayah seperti kecamatan Manggelewa misalnya, sejumlah SD hanya diisi 2-3 guru terdiri atas guru agama dan guru olahrga saja. Di sebagian besar sekolah kontribusi GTT sangat besar (sekitar 80\%) dibandingkan guru PNS yang berjumlah 2.650 orang.

Kurniawan Ahmadi menyatakan bahwa jika pada zaman Bupati Syaifurrahman tahun 2009 dengan PAD yang hanya Rp 514 milyar saja berani memberikan pendidikan dan kesehatan gratis, mengapa sekarang dengan PAD sebesar Rp 619 milyar malah tidak ada? Dia menyatakan bahwa pasangan MULYA mengusung slogan "Membangun Desa Menata Kota" didasari kesadaran bahwa "desa adalah lapisan terbawah kesejahteraan masyarakat. Ibarat pohon, desa adalah akar. Jika akarnya tidak disiram maka daun-daunnya akan layu". Sementara Cabup Mulyadin menyatakan keprihatinnya atas rendahnya harga jual udang maupun hasil pertanian seperti jagung. Dia menjanjikan akan memperjuangkan stabilitas harga serta memfasilitasi pembentukan asosiasi nelayan dan petani untuk meningkatkan posisi tawar petani dan nelayan. Mulyadi juga menawarkan semacam Kartu Jakarta Pintar (KJP) ala (bekas) Gubernur DKI Jakarta Joko Widodo, yang dapat digunakan masyarakat untuk ditukarkan dengan berbagai kebutuhan masyarakat seperti mesin ketinting, sumur bor dalam dll yang akan berlaku selama masa pemerintahannya. Mulyadin juga menegaskan bahwa keberhasilan pembangunan tidak hanya diukur dari aspek fisik seperti jagung dan pembangunan infrastruktur seperti pembangunan pasar dan fasilitas lainnya tapi juga harus membangun aspek sosial budaya. Karena itu dia mencanangkan program "Magrib Mengaji" serta meluncurkan Balai Mengaji di 8 desa. Program "Magrib Mengaji" dimaksudkan agar masyarakat terutama anak-anak hendaknya mengaji setelah salat Magrib baik di rumah maupun di masjid.

Mulyadin juga menjanjikan perubahan dalam pelayanan pemerintahan serta hendak membangun demokrasi yang bermartabat dengan menghilangkan politik uang dalam tata pemerintahannya. Selama ini, menurutnya, tata pemerintahan sudah sangat diwarnai politik uang sejak dari jenjang terendah seperti pemilihan Kadus dan Kades hingga pengangkatan pejabat kepala dinas. Praktik tersebut sudah terjadi di Dompu sejak 15 tahun terakhir. Di bidang pendidikan, Mulyadin menjanjikan akan menaikan gaji GTT dari Rp 100 ribu-150 ribu sebulan menjadi Rp 300 ribu perbulan. "Jika gaji GTT masih Rp 100-150 ribu perbulan maka untuk apa dilanjutkan?" sambil menyindir slogan petahana paslon HBY-Arif yang mengusung jargon "Lanjutkan!". Mulyadin juga menjanjikan akan mengangkat guru-guru mengaji menjadi tenaga kontrak daerah. 
Sementara itu, dalam Rapat Terbatas di Desa Jambu Kec. Pajo tanggal 29 September 2015 Paslon Lamba Rasa menjanjikan perbaikan infrastruktur nelayan seperti rehabilitasi pelabuhan serta bantuan untuk nelayan seperti sampan. Sedangkan di bidang pendidikan menjanjikan bantuan perlengkapan sekolah (buku, seragam sekolah). Anggota Tim Kampanye Lamba Rasa Ikhwayuddin AK (juga Ketua Fraksi PAN di DPRD Kabupaten Dompu) mempertanyakan mengapa pendidikan (di jenjang pendidikan dasar dan menengah) dan kesehatan harus dibiayai lagi masyarakat, sedangkan sebelumnya pendidikan dan kesehatan gratis sudah berjalan. Dia menyatakan bahwa jika terpilih maka Paslon Lamba Rasa memastikan selama lima tahun memegang pemerintahan maka tidak akan ada lagi masyarakat Dompu yang putus sekolah maupun tidak mampu membayar biaya berobat dengan Program Pendidikan dan Kesehatan Gratis. Dia juga banyak mengeritik kebijakan pembangunan Pemda yang lebih berorientasi proyek-proyek fisik seperti pembangunan gedung Paruga Samakai hanya karena Pemda mendapat konsesi 10\% dari kontraktor daripada pembangunan dam-dam yang lebih dibutuhkan oleh rakyat. Dia juga menjanjikan jika paslon Lamba Rasa memenangkan Pilkada akan menyediakan bantuan modal maupun membuka lapangan kerja untuk para pemuda maupun kaum ibu sehingga mereka memiliki usaha produktif dan tidak perlu menjadi TKI/TKW seperti yang berlangsung selama ini. Paslon Lamba Rasa juga akan memberikan bantuan untuk nelayan maupun petani seperti perahu dan alat tangkap. Sementara Cabup Syarifuddin Yasin menjanjikan, jika dirinya terpilih maka akan mengunjungi masyarakat setiap saat. Dia juga meyakinkan bahwa dirinya mengikuti pencalonan bupati Dompu bukan untuk mencari kekayaan pribadi melainkan untuk mengabdikan diri untuk masyarakat Dompu. Dia juga mengklaim memiliki akses untuk mendapatkan sumber-sumber dana di Pemerintah Pusat (Jakarta).

Sementara itu, Cawabup Paslon OK Kisman dalam kampanye di Kelurahan Monta Kec. Woja tanggal 1 Desember 2015 menyatakan pasangan OK bertekad mengembalikan program pendidikan dan kesehatan gratis sebagaimana dijalankan pada saat Ompu menjadi Bupati Dompu periode sebelumnya. Khusus di bidang pendidikan program pendidikan gratis bahkan akan diperluas hingga tingkat SMA dibandingkan sebelumnya dari jenjang SD sampai SMP. Begitu juga untuk anakanak kurang mampu yang hendak melanjutkan pendidikan ke jenjang perguruan tinggi (PT), akan dibiayai asalkan memiliki prestasi akademik maupun prestasi nonakademik yang baik. Begitu pula untuk para guru yang berprestasi tapi hendak menempuh jenjang pendidikan lebih tinggi akan dikuliahkan secara gratis. Paslon OK mengeritik penghapusan program pendidikan dan kesehatan karena simpulan yang keliru yakni masyarakat Dompu sudah sejahtera (kaya).

Kisman memastikan bahwa pihaknya juga akan mengharamkan penyuapan dalam pengangkatan kepala sekolah seperti yang terjadi selama ini yang ditengarai melakukan penyuapan antara Rp20-30 juta. Pengangkatan kepala sekolah akan dilakukan berdasarkan prinsip senioritas. Paslon OK akan memberikan gaji kepada guru honor Rp 900 ribu seperti di zaman Ompu dahulu. "Sekarang gaji guru honor malah diturunkan menjadi Rp700 ribu," tukas Kisman. OK menjanjikan gaji guru honor Rp 1 juta sebulan sedangkan Guru Tidak Tetap (GTT), Guru Tetap Yayasan (GTY), guru TK, guru PAUD, kader Posyandu, guru ngaji, dan ketua RT diberi gaji Rp500 ribu. Sedangkan untuk birokrasi, pasangan $\mathrm{OK}$ akan mengembalikan program pembagian pakaian dinas secara gratis. Pihaknya juga menjamin tidak ada praktik suap dalam tes CPNS maupun perekrutan pegawai honor daerah.

\section{B. Pembahasan}

Bila dicermati terdapat beberapa fakta menarik tentang isu dan kebijakan pendidikan dalam konteks kampanye Pilkada Dompu. Pertama, tidak seluruh Paslon merumuskan visi, terlebih memiliki visi pendidikan, secara sistematis dan komprehensif. Absennya bidang pendidikan dalam visi (sebagian) para Paslon bupati tersebut menunjukkan bahwa sektor pendidikan seolah menjadi sektor yang diabaikan dan dianggap tidak penting dalam keseluruhan rancang-bangun pembangunan di daerah. Sebaliknya, isu dan kebijakan di bidang-bidang ekonomi, infrastruktur, dan peningkatan kesejahteraan birokrasi jauh lebih mendapat perhatian. Secara teoretis hal tersebut dapat dimaklumi karena, kendatipun kebijakan pendidikan disadari sangat penting bagi transformasi sosial individu dan masyarakat baik secara ekonomis maupun aktualisasi nilai-nilai kemanusiaan, namun kebijakan pendidikan bukanlah sesuatu yang berdiri sendiri melainkan dipengaruhi oleh faktor-faktor lain seperti politik, budaya, maupun ekonomi. 
Dalam kampanye Pilkada Dompu, kecilnya perhatian para Paslon terhadap kebijakan pendidikan dalam derajat tertentu dapat dipahami dari perspektif di atas. Sebagai daerah yang masih didera oleh berbagai kemiskinan dan keterbelakangan maka 'wajar' bila para Paslon belum menjadikan isu pendidikan sebagai isu utama dalam kampanye-kampanye mereka. Sebaliknya, fokus isu para Paslon lebih besar pada persoalan-persoalan kongkret yang dihadapi oleh masyarakat seperti pemenuhan kebutuhan dasar, pangan, kesejahteraan ekonomi, lapangan kerja serta pembangunan infrastruktur. Isu-isu seputar pemenuhan kebutuhan dasar masyarakat dipandang lebih populis dan karenanya secara politik lebih menguntungkan dibandingkan dengan isu pendidikan yang relatif dipandang 'mewah'.

Kendati demikian, tidak berarti bahwa kemiskinan ekonomi menjadi satu-satunya alasan bagi suatu daerah untuk tidak menjadikan kebijakan pendidikan sebagai arus-utama (mainstream) kebijakan kepala daerah. Sebab hal itu sangat tergantung pada visi dan kepedulian pemimpin bersangkutan. Jika kebijakan pendidikan dipandang sebagai bagian dari kebijakan pembangunan lainnya maka pendidikan pun akan diperlakukan sama dengan kebijakan lainnya seperti kebijakan bidang ekonomi, sosial, militer dan lain-lain. Dalam konteks ini, sebagai wilayah tanggung jawab pemerintah pendidikan juga sering "dipaksa" menyesuaikan diri dengan pola-pola administratif umum dan norma-norma yang berlaku. Akibatnya, "pendidikan publik dibiayai dan dikontrol oleh pemerintah seperti pemerintah membiayai dan mengontrol bidang-bidang lainnya seperti pertanian, kesehatan, atau pelayanan sosial" (Sirozi, 2005: 17). Padahal sebagai upaya humanisasi (humanizing), kebijakan pendidikan memerlukan pola pendekatan dan perlakuan yang juga manusiawi. Pada kampanye Pilkada Dompu terlihat bahwa visi dan kebijakan pendidikan dari Paslon hanya sekadar bagian terkecil dari isu-isu utama dalam kampanye-kampanye mereka.

Persoalan kedua, adalah isu dan kebijakan pendidikan dari Paslon cenderung terkesan instan dan belum bersifat strategis seperti pelayanan pendidikan gratis, penyediaan perlengkapan sekolah, menaikkan tunjangan guru honorer, pemberian beasiswa, serta mengarahkan lulusan agar terserap dalam pabrik maupun perusahaan tambang. Meskipun demikian, ada juga Paslon yang menyoroti ketimpangan distribusi guru-guru di daerah perkotaan dan pedesaan, kendatipun belum dilengkapi dengan pemetaan di tiap kecamatan serta data-data yang memadai. Munculnya kebijakan-kebijakan pendidikan yang bersifat instan tersebut seolah mengkonfirmasi bahwa pembuatan kebijakan-kebijakan publik, termasuk kebijakan pendidikan, seringkali tidak berdasarkan analisis kebijakan yang memadai. Padahal dengan memanfaatkan hasil analisis kebijakan yang telah ada maka di samping terhindar dari pembuatan kebijakan yang keliru juga dapat menghemat berbagai sumberdaya.

Bila dicermati maka isu dan kebijakan-kebijakan pendidikan dalam kampanye dari para Paslon bupati Dompu tidak bersifat strategis dan komprehensif. Bahkan kebijakan pendidikan gratis misalnya, sekadar menduplikasi kebijakan nasional karena hal itu merupakan amanat dari UU No. 20 Tahun 2003 tentang Sisdiknas sehingga penerapan kebijakan tersebut tidak dapat dipandang sebagai 'kemurahan hati' atau bentuk keberpihakkan pemimpin di daerah terhadap dunia pendidikan. Dalam pasal 11 ayat (1) dijelaskan bahwa "Pemerintah dan pemerintah daerah wajib memberikan layanan dan kemudahan, serta menjamin terselenggaranya pendidikan yang bermutu bagi setiap warga negara tanpa diskriminasi" dan pada ayat (2) "Pemerintah dan pemerintah daerah wajib menjamin tersedianya dana guna terselenggaranya pendidikan bagi setiap warga negara yang berusia tujuh sampai dengan lima belas tahun". Bahkan secara spesifik, dalam kaitannya dengan pendanaan pasal 49 ayat (1) menegaskan bahwa pemerintah wajib mengalokasikan minimal 20\% APBN maupun APBD untuk sektor pendidikan. Dengan demikian, keharusan untuk menjamin terlaksananya pendidikan yang murah dan berkualitas, terutama di jenjang pendidikan dasar (SD-SMP/sederajat), sudah merupakan sine quo non, mutlak dan inheren dalam kebijakan pembangunan nasional dan daerah. Di luar hal itu, kewajiban untuk menyelenggarakan pendidikan yang murah dan berkualitas bagi masyarakat merupakan amanat konstitusi yang harus ditunaikan oleh pemerintah untuk "mencerdaskan kehidupan bangsa".

Dapat dikatakan bahwa secara umum kebijakan-kebijakan pendidikan yang ditawarkan para Paslon dalam kampanye Pilkada Dompu masih berkutat pada hal-hal yang bersifat fisik atau finansial seperti pendidikan gratis, penyediaan perlengkapan sekolah, pemberian beasiswa dan sejenisnya. Padahal sebagaimana diingatkan Arcaro (1997: 2) bahwa kunci peningkatan mutu pendidikan tidak semata ditentukan oleh ketersediaan dana. Arcaro menolak pandangan bahwa 
jika dana telah tersedia dalam jumlah cukup secara otomatis dapat meningkatkan mutu pendidikan. Padahal pencapaian mutu tersebut ditentukan oleh kualitas personil yang ada baik kepala sekolah, guru, tenaga kependidikan maupun komite sekolah/dewan pendidikan dalam membangun kerjasama bagi kemajuan sekolah. Masih menurut Arcaro (1997: ix) bahwa keberhasilan reformasi di bidang pendidikan mengharuskan pelibatan semua pemangku kepentingan dan harus dilihat sebagai bagian integral dari kehidupan sosial secara keseluruhan. Sejalan dengan itu Beeby (1982: 4) juga mempertanyakan setiap kebijakan pendidikan yang hanya mengandalkan pertimbangan finansial.

Pada kampanye Pilkada Dompu, terlihat bahwa para Paslon belum menyentuh aspek-aspek kebijakan pendidikan yang lebih komprehensif, sistematis dan terintegrasi. Misalnya tentang peningkatan kapasitas (capacity building) tenaga pendidik dan kependidikan yang dilakukan secara sistematis dan berkelanjutan, kepastian dalam jenjang karir, pembatasan masa jabatan kepala sekolah, penggabungan sejumlah sekolah yang kekurangan murid, penyediaan bis sekolah, penyediaan makanan tambahan untuk anak sekolah dan lain-lain. Sebagian kecil isu strategis pendidikan tampaknya sudah muncul dalam kampanye Paslon seperti persoalan ketimpangan distribusi guru antarwilayah (sebagaimana dikemukakan Paslon MULYA) maupun tekad menghilangkan praktek 'penyerahan upeti' yang ditengarai terjadi dalam pengangkatan kepala sekolah (Paslon OK), namun juga jelas kiranya bahwa berbagai persoalan mendasar pendidikan di Dompu sebagaimana dikemukakan di atas belum tersentuh.

Masalah peningkatan kemampuan mengajar guru misalnya, merupakan salah satu persoalan yang luput dan diabaikan dalam wacana kebijakan peningkatan mutu pendidikan. Padahal sudah lama menjadi rahasia umum bahwa seorang pegawai negeri di Indonesia, termasuk guru, rata-rata hanya mendapatkan program-program pelatihan peningkatan kemampuan profesionalnya hanya sekali selama 20 tahun, belum lagi guru-guru di sekolah swasta. Hal tersebut berakibat pada lemahnya kemampuan profesional guru dan akhirnya berdampak terhadap rendahnya kualitas pendidikan secara keseluruhan. Demikian juga dengan peningkatan kemampuan kepala sekolah. Meski di Dompu dalam satu tahun terakhir ini sudah mulai dilakukan pembenahan berupa pelatihan Cakep (calon kepala sekolah), namun kebijakan semacam itu belum ditindaklanjuti secara serius. Sebagian kalangan pendidikan menganggap program pelatihan Cakep hanya 'formalitas' saja karena akhirnya tetap ditentukan oleh faktor kedekatan, pendekatan, uang dan lobi-lobi politik. Di kalangan pelaku pendidikan di Dompu berkembang beberapa istilah untuk menyindir kecenderungan ini misalnya, bahwa untuk mendapatkan jabatan-jabatan yang lebih tinggi seperti kepala sekolah atau kepala dinas pendidikan kecamatan tidak hanya ditentukan oleh "garis tangan" tapi juga "jabat tangan dan buah tangan", atau dalam istilah lokal harus memiliki "pi" dan "pa". Dalam bahasa Bima "Pi" adalah akronim "piti" (uang) dan "pa" adalah "pata" (kenalan). Artinya, kepastian jenjang karir kependidikan tidak semata ditentukan oleh kompetensi tapi juga karena faktor uang dan pertemanan dan koneksi dengan sumber-sumber kekuasaan. Di sisi lain, juga berkembang asumsi keliru sebagian pelaku pendidikan di Dompu yang memandang seolah-olah jabatan kepala sekolah merupakan pencapaian tertinggi dalam karir seorang pendidik.

Akibatnya, kendati regulasi menetapkan bahwa jabatan sebagai kepala sekolah hanyalah 'tugas tambahan', namun asumsi keliru semacam ini sudah telanjur berkembang sehingga berimplikasi pada pandangan bahwa jabatan kepala sekolah seolah menjadi simbol prestise dan status sosial dan, karenanya, harus dikejar dan diperebutkan dengan segala cara, termasuk dengan upaya praktek penyuapan sebagaimana ditengarai sebagian kalangan selama ini. Sinyalemen ini muncul, salah satunya, disebabkan ketidakjelasan mekanisme pengangkatan dalam jabatan kepala sekolah. Akibatnya, setiap kali dilakukan promosi dan mutasi birokrasi seringkali menimbulkan 'kegaduhan' bahkan 'keguncangan' di tengah publik karena selalu dipersepsi dalam kerangka 'hukuman' dan 'anugerah'. Dipersepsi sebagai 'hukuman' (punishment) jika jabatan baru tersebut tergolong 'kering' secara ekonomis atau posisinya lebih rendah dari sebelumnya. Sebaliknya, akan dipersepsi sebagai anugerah dan keberuntungan jika seseorang mendapatkan jabatan baru yang lebih tinggi, terlebih lagi jika mengalami 'lompatan' jabatan dari biasanya. Sebaliknya, jika mekanisme tersebut didasarkan pada indikator-indikator yang transparan dan akuntabel maka timbulnya ekses-ekses yang tidak produktif tersebut dapat dihindarkan.

Di Indonesia beberapa contoh baik (best practice) dalam terobosan dan inovasi-inovasi kebijakan pendidikan telah dilakukan misalnya, di Kabupaten Jembrana, sebuah kabupaten 
termiskin di Bali. Sebagaimana ditemukan Nugroho (2008) bahwa Pemerintah Kabupaten Jembrana berhasil melakukan beberapa inovasi dalam kebijakan pendidikan seperti penggabungan beberapa sekolah (termasuk penggabungan sejumlah kantor pemerintah) maupun pembatasan masa jabatan kepala sekolah. Di Jembrana jabatan kepala sekolah hanya berlaku dua periode dan setelah itu menjadi guru biasa karena sesuai dengan regulasi nasional bahwa jabatan kepala sekolah merupakan tugas tambahan, sedangkan tugas pokoknya adalah tetap sebagai guru. Penegakkan aturan semacam ini diperlukan untuk mencegah timbulnya asumsi keliru sebagaimana dikemukakan di atas bahwa jabatan kepala sekolah seolah menjadi lambang prestise dan status sosial seseorang. Lebih dari itu, penegakkan regulasi ini dilakukan karena berdasarkan sejumlah temuan bahwa ternyata banyak kepala sekolah, pengawas, dan guru-guru senior yang tidak lolos dalam uji kompetensi sertifikasi.

Dalam konteks Dompu masalah penggabungan sekolah yang tidak efisien juga sangat mendesak dilakukan. Tapi rupanya isu ini tergolong sensitif sehingga cenderung dihindari para Paslon karena dianggap tidak menguntungkan secara elektoral. Sebab jika isu merger sekolah ini dilakukan tentu akan menimbulkan sejumlah implikasi seperti bagaimana merelokasi jabatan bagi kepala sekolah, guru, hingga guru honorer pada sekolah yang dimerger. Padahal suara dan dukungan para pelaku pendidikan di tingkat bawah ini dipandang signifikan oleh para Paslon. Selain persoalan efisiensi anggaran, kendala alat transportasi juga merupakan masalah yang sering dihadapi terutama oleh peserta didik khususnya di daerah-daerah pedesaan. Hal ini disebabkan oleh kendala geografis maupun demografis dimana sebagian masyarakat bertempat tinggal secara terpencar-pencar sehingga berpengaruh terhadap kinerja pendidikan (educational performance) khususnya dari aspek tingkat kehadiran peserta didik di sekolah. Oleh karena itu, diperlukan kebijakan-kebijakan pendidikan yang antisipatif dan progresif untuk memecahkan masalah tersebut, misalnya dengan pengadaan angkutan khusus sekolah. Demikian pula, diperlukan kebijakan-kebijakan pendidikan yang lebih populis untuk merangsang peningkatan persentase kehadiran peserta didik di sekolah, antara lain kebijakan pengadaan makan siang gratis di sekolah sebagaimana diterapkan di India.

Berbagai inovasi kebijakan pendidikan semacam ini maupun mengadopsi beberapa best practice yang ada sangat diperlukan agar wacana-wacana kebijakan pendidikan tidak hanya berkutat pada persoalan-persoalan konvensional (seperti pendidikan gratis) namun mampu melampaui berbagai masalah pendidikan yang muncul di masa mendatang. Di atas semua itu, pendidikan sebagai satusatunya instrumen yang efektif untuk meningkatkan kemampuan dan daya saing sebuah bangsa membuktikan bahwa investasi pendidikan akan berpengaruh secara langsung terhadap peningkatan kualitas SDM dan daya saing bangsa tersebut. Beberapa studi yang dilakukan Bank Dunia menunjukkan bahwa investasi pendidikan sebagai kegiatan inti pengembangan SDM terbukti telah memiliki sumbangan yang sangat signifikan terhadap tingkat keuntungan ekonomi (MC Mochan dan Boediono 1992 dalam Fatah 2009). Berdasarkan temuan studi tersebut bahwa keuntungan ekonomi (rate of return) investasi pendidikan ternyata lebih tinggi daripada investasi fisik dengan perbandingan rata-rata 15,3\% dan 9,1\%. Ini berarti bahwa investasi dalam pendidikan merupakan upaya yang menguntungkan baik secara sosial maupun ekonomis (Fatah, 2009: 79). Secara demikian maka sudah seharusnya kebijakan-kebijakan pendidikan dijadikan arus utama (mainstream) dalam rancang-bangun pembangunan di daerah, termasuk dalam kampanyekampanye politik pemilihan kepala daerah.

\section{SIMPULAN DAN SARAN}

\section{A. Simpulan}

Berdasarkan pembahasan sebelumnya maka dapat disimpulkan beberapa hal sebagai berikut:

1. Pendidikan belum menjadi isu utama dalam tema-tema kampanye para kandidat yang bertarung dalam Pilkada Kabupaten Dompu 2015; isu-isu pendidikan berada dalam posisi sejajar bahkan---bagi sebagian Paslon---disubordinasikan dengan tema-tema kampanye lainnya seperti pembangunan infrastruktur, peningkatan kesejahteraan ekonomi serta perbaikan kesejahteraan pegawai.

2. Isu kebijakan pendidikan dalam kampanye para Paslon masih berkisar pada perdebatan pendidikan gratis, sedangkan beberapa persoalan nyata pendidikan maupun memunculkan 
inovasi-inovasi baru di bidang kebijakan pendidikan tidak muncul sama sekali. Memang, ada satu Paslon yang mulai menyoroti ketimpangan distribusi guru antara daerah perkotaan dan pedesaan, tapi juga jelas masih banyak masalah strategis pendidikan yang belum tersentuh seperti efisiensi penyelenggaraan pendidikan, perbaikan kualitas sumberdaya tenaga pendidik dan tenaga kependidikan maupun kejelasan dan kepastian dalam jenjang karir tenaga pendidik dan tenaga kependidikan.

3. Pembenahan kebijakan-kebijakan pendidikan dalam kampanye para Paslon masih sangat kuat menggunakan pendekatan 'kesejahteraan' dalam mengatasi persoalan pendidikan seperti pemberian remunerasi, beasiswa, perlengkapan sekolah dan sejenisnya. Sedangkan persoalan-persoalan etos kerja, budaya dan mental cenderung diabaikan. Dengan kata lain, berbagai persoalan pendidikan cenderung dilihat dengan menggunakan pendekatan kuratif, seolah dengan mengandalkan basis-basis material dapat menyelesaikan masalah pendidikan dengan sendirinya.

\section{B. Saran}

Tidak seperti sektor pembangunan fisik yang langsung kelihatan hasilnya, tapi sebagai sebuah investasi jangka panjang pendidikan jelas sangat mempengaruhi perubahan sosial dalam suatu masyarakat. Oleh karena itu para Paslon yang bertarung harus menjadikan isu pendidikan sebagai konsen utama dalam kampanye Pilkada bersama sektor-sektor lainnya. Dengan kewenangan yang dimilikinya sekarang para kepala daerah dapat menggunakan sektor pendidikan sebagai instrumen untuk mendorong transformasi sosial ekonomi di daerahnya.

\section{DAFTAR RUJUKAN}

Arcaro, S. 1997. Quality in Education: An Implementation Handbook. New Delhi: Vanity Books International.

Badan Pusat Statistik. 2008. Buku Saku 2008. Mataram: BPS.

CE. Beeby. 1982. Pendidikan di Indonesia: Penilaian dan Pedoman Perencanaan, terj. BP3K dan YIIS. Jakarta: LP3ES.

Fatah, N. 2009. Ekonomi\&Pembiayaan Pendidikan. Bandung: Rosdakarya.

Miles, M.B\&Huberman, AM. 1985. Qualitative Data Analysis. California: Sage Publication.

Nugroho, R. 2008. Kebijakan Pendidikan yang Unggul: Kasus Pembangunan Pendidikan di Kabupaten Jembrana 2000-2006. Yogyakarta: Pustaka Pelajar.

Pramusinto, A. 2010. "Desentralisasi dan Kepemimpinan Inovatif di Indonesia," Sosiohumaniora, vol. 12, no. 3, h. 307-308, Nov.

Razik, T\&Swanson, A. 1995. Fundamental Concepts of Educational Leadership and Management. New Jersey: Prentice-Hall.

Sirozi, M. 2007. Politik Pendidikan. Jakarta: Rajawali Press.

Sulistyastuti, R. 2007. "Pembangunan Pendidikan dan MDGs di Indonesia: Sebuah Refleksi Kritis," Jurnal Kependudukan Indonesia, Vol. II, No. 2, h. 19, April.

Tilaar, HAR \& Nugroho, R. 2008. Kebijakan Pendidikan. Yogyakarta: Pustaka Pelajar.

Tim Penyusun KPU Kabupaten Dompu, 2015. Buku Data dan Infografik Pemilihan Bupati \& Wakil Bupati Dompu Tahun 2015. Dompu: KPU Kabupaten Dompu. 
UNESCO, Learning to be. 1972. Paris: UNESCO.

UU No. 20 Tahun 2003 tentang Sistem Pendidikan Nasional.

Kompas, 2009. 8 April.

Kompas, 2009. “Kinerja Guru Rendah, Produktivitas Tinggi Saat Mengikuti Sertifikasi”, 7 Oktober.

Kompas, 2009. “Guru Dituntut Perbaiki Kinerja”, 25 November.

Jurnal KPU Kabupaten Dompu. 2015."7 Kabupaten/Kota di NTB Gelar Pilkada Serentak”. Edisi JuliAgustus

Suara KPU, 2015. Edisi Maret-April.

Inti Rakyat, 2015. “OK [Ompu-Kisman] Tawarkan 14 Program untuk Semua”, 28 September.

Inti Rakyat, 2015. "Paslon LR [Lamba Rasa] Janjikan Kesejahteraan Rakyat”, 28 September.

Inti Rakyat, 2015. “Membangun Mulai dari Desa”, 28 September. 